2010

\title{
Observations Of Blue Crabs (Callinectes Sapidus, Rathbun 1896) On Shell Bar Oyster Reef, Great Wicomico River, Virginia
}

Juliana Harding

Virginia Institute of Marine Science

Melissa Southworth

Virginia Institute of Marine Science

Roger L. Mann

Virginia Institute of Marine Science

Follow this and additional works at: https://scholarworks.wm.edu/vimsarticles

Part of the Aquaculture and Fisheries Commons

\section{Recommended Citation}

Harding, Juliana; Southworth, Melissa; and Mann, Roger L., Observations Of Blue Crabs (Callinectes Sapidus, Rathbun 1896) On Shell Bar Oyster Reef, Great Wicomico River, Virginia (2010). Journal Of Shellfish Research, 29(4), 995-1004.

10.2983/035.029.0435

This Article is brought to you for free and open access by the Virginia Institute of Marine Science at W\&M ScholarWorks. It has been accepted for inclusion in VIMS Articles by an authorized administrator of W\&M ScholarWorks. For more information, please contact scholarworks@wm.edu. 


\title{
OBSERVATIONS OF BLUE CRABS (CALLINECTES SAPIDUS, RATHBUN 1896) ON SHELL BAR OYSTER REEF, GREAT WICOMICO RIVER, VIRGINIA
}

\author{
JULIANA M. HARDING,* MELISSA J. SOUTHWORTH AND ROGER MANN \\ Virginia Institute of Marine Science, College of William \& Mary, Gloucester Point, VA 23062
}

\begin{abstract}
Blue crabs (Callinectes sapidus, Rathbun 1896) were sampled with commercial crab pots on Shell Bar oyster reef in the Great Wicomico River, VA, from May through October during 2006 and 2007. Weekly catch per unit effort (CPUE), sex ratio, and size (carapace width, measured in millimeters) were evaluated in the context of water temperature (measured in degrees Celsius), salinity, and daylength (measured in hours) conditions on the reef. The total number of crabs collected in 2006 and 2007 was 5,221 and 3,303, respectively. Blue crab CPUE was highest from mid-June through mid-September at water temperatures at or more than $26^{\circ} \mathrm{C}$, with maximum CPUEs observed in late July. The overall annual ratio of females to males was 0.47 in 2006 and 0.60 in 2007. Males made up more than $50 \%$ of the catch at Shell Bar reef from May through August. The observed sex ratio shifted from male dominated to female dominated as salinity increased, whereas water temperature and daylength decreased seasonally. Female crabs (median carapace width $(\mathrm{CW}), 142-144 \mathrm{~mm}$ ) were approximately $20 \mathrm{~mm}$ in $\mathrm{CW}$ larger than males (median CW, $125 \mathrm{~mm}$ ) in both years. Annual average CPUE (13.42 crabs per pot; SE $=1.57)$ and maximum CPUE (32.06 crabs per pot) was twice as high in 2006 as it was in 2007. The observed interannual differences in crab CPUEs may be the result of an enhanced forage base on the reef in 2006 relative to 2007. Approximately 9 million cultchless oysters ( $40-80 \mathrm{~mm}$ in shell height) were planted on Shell Bar reef between May and October 2006 as part of a concurrent oyster rehabilitation program.
\end{abstract}

KEY WORDS: blue crab, Callinectes sapidus, oyster reef, Crassostrea virginica, habitat, Great Wicomico River

\section{INTRODUCTION}

Blue crabs (Callinectes sapidus, Rathbun 1896) use temperate estuaries from Cape Cod to Brazil as mating and feeding habitats (Millikin \& Williams 1984, Hines et al. 1995). Estuarine habitat use by blue crabs varies in relation to seasonal environmental conditions (Churchill 1919, Van Engel 1958, Hines et al. 1987, Anguilar et al. 2005, Harding \& Mann 2010) as well as ontogeny (e.g., Van Engel 1958, Orth 1977, Virnstein 1977, Orth \& von Montfrans 1987, Sogard \& Able 1994, Minello 1999, Seitz et al. 2005). Crab stocks in the Chesapeake Bay are at or near historic lows (Rugulo et al. 1998, Chesapeake Bay Blue Crab Advisory Report 2007, Chesapeake Bay Blue Crab Advisory Report 2008) as a result of a combination of environmental and anthropogenic factors including fishing pressure. Current crab management efforts in the Chesapeake Bay incorporate information on seasonal population dynamics and habitat use in an effort to establish protected migration corridors and sanctuary areas (Lipcius \& Stockhausen 2002, Lipcius et al. 2003; Anguilar et al. 2005) and to reduce mortality to stabilize and rebuild the stock (e.g., Lipcius \& Van Engel 1990).

Blue crabs are mobile predators that readily consume oysters (Crassostrea virginica, Gmelin, 1791 (Eggleston 1990a, Eggleston 1990b)) as well as infaunal bivalves (e.g., Virnstein 1977, Hines et al. 1990, Seitz et al. 2003). Oysters less than $50 \mathrm{~mm}$ in shell height are particularly vulnerable to predation by mature (carapace width $(\mathrm{CW}),>100 \mathrm{~mm}$ ) crabs (Eggleston 1990a, Eggleston 1990b). Oyster communities are an important crab foraging habitat in temperate estuaries (e.g., Minello 1999, Posey et al. 1999, Coen \& Luckenbach 2000, Glancy et al. 2003). The Chesapeake Bay oyster population has declined drastically in absolute numbers as well as the spatial footprint occupied by biogenic oyster reefs since the late 19th century (e.g., Haven et al. 1981, Rothschild et al. 1994, Hargis \& Haven 1999).

*Corresponding author. E-mail: jharding@vims.edu
Recent rehabilitation and construction efforts for oyster reefs in the Chesapeake Bay may enhance local crab production by enhancing the habitat heterogeneity and forage base (e.g., Coen et al. 1999, Peterson et al. 2003, Harding \& Mann 2010). Thus, focused efforts to rebuild oyster populations within Bay tributaries may provide indirect habitat enhancement for crabs at local (kilometer) spatial scales. Our objectives were to describe quantitatively the blue crab catch per unit effort (CPUE) and demographics around a constructed oyster reef in the Great Wicomico River between 2006 and 2007, and to relate these observations to environmental conditions (water temperature, salinity, and daylength). In small temperate estuaries like the Great Wicomico River, daylength provides a regular seasonal environmental baseline, unlike water temperature and salinity, which may show wide intra- and interannual variation (Harding \& Mann 2010).

\section{METHODS}

\section{Sampling Site}

Blue crabs were collected on Shell Bar oyster reef $\left(36.8294^{\circ}\right.$ $\mathrm{W}, 76.8139^{\circ} \mathrm{N}$ ) in the Great Wicomico River, VA. The Great Wicomico River is a small $182.8-\mathrm{km}^{2}$ drainage basin (Hyer \& Jacobson 1976) trap-type estuary (Andrews 1979) on the western shore of the Chesapeake Bay between the Potomac and Rappahannock Rivers. The lower portion of the estuary has been the site of multiagency oyster replenishment efforts beginning in 1996 (Southworth \& Mann 1998) with increased research and monitoring efforts from 2004 through 2007 (see www.vims.edu/mollusc/NORM/index.htm). Shell Bar reef is an intertidal, 3-dimensional oyster reef that was constructed in fall 1996 by the Virginia Marine Resources Commission Shellfish Replenishment Program (Southworth \& Mann 1998). The reef is a series of oyster shell mounds constructed on a northwest/ southeast axis parallel to the southwestern shoreline, with a spatial footprint of approximately 0.8 ha. Maximum depth at 
the reef edge is approximately $4 \mathrm{~m}$. Mean tidal range in the Great Wicomico River is approximately $2.5 \mathrm{~m}$.

\section{Sampling Protocol}

The perimeter of Shell Bar reef was enclosed by a net "fence" made of gill netting (mesh size, $30.5 \mathrm{~cm}$ ) moored at the surface and bottom to pilings spaced at 3 to $4-\mathrm{m}$ intervals around the reef perimeter. The top of the net fence extended approximately $2 \mathrm{~m}$ above MLW and the bottom was firmly anchored between pilings. The fence was built to exclude cownose rays (Rhinoptera bonasus) during 2006 and 2007 as part of a larger multiyear monitoring program (www.vims.edu/mollusc/NORM/index. htm (Mann et al. 2008)), but blue crabs were not excluded from the reef by the net enclosure. The net enclosure was serviced and cleaned twice weekly from May through October in 2006 and 2007 to maintain water flow and full mesh expansion by managing and/or eliminating fouling.

Crabs were collected on Shell Bar reef within the net enclosure perimeter. The individual sampling unit was a commercial crab pot (a 61-cm cube with a 5.08-cm cull ring). The mesh size (38 $\mathrm{mm}$ ) and cull ring of the sampling gear set an effective lower limit of approximately $100-\mathrm{mm} \mathrm{CW}$ for the crabs sampled by this study. Crabs with a CW less than $100 \mathrm{~mm}$ are capable of escaping from the pots used. Nine commercial crab pots were hung from the pilings on the inside of the net enclosure at even intervals around the reef perimeter. Crab pots were baited with menhaden and were fished from May 1 through October 31 each year. After recovery, crabs from all pots were pooled, measured $(\mathrm{CW}$, in millimeters), sexed, and released. Soak time was typically 3-4 days but some weather events forced changes in this schedule. Data from sampling events within a week (7 day, Sunday to Saturday) were pooled and standardized by week to incorporate weather-related variations in sampling. The week of the year (WOY) assigned for a collection was the WOY during which the crab pots were removed from the water and emptied.

Water temperature (measured in degrees Celsius) and salinity measured $0.25 \mathrm{~m}$ above the bottom every $15 \mathrm{~min}$ by a YSI XL-600 (Yellow Springs Instruments, Yellow Springs, OH) series sonde moored on Shell Bar reef were used to calculate average weekly water temperature and salinity values (with SEM). Average weekly daylength (measured in hours, time between sunrise and sunset) was calculated from daily sunrise and sunset times (measure in hours (www.usno.navy.mil/USNO), May through October 2006 and 2007) reported for Glebe Point $\left(38.847^{\circ} \mathrm{N}, 76.369^{\circ} \mathrm{W}\right)$, Great Wicomico River, VA.

\section{Data Analyses}

Total weekly crab CPUE and the proportion of the CPUE contributed by males from May through October in 2006 and 2007 were evaluated with regard to water temperature, salinity, and daylength. CPUE is defined as the number of blue crabs caught in $1 \mathrm{crab}$ pot during $1 \mathrm{wk}$, and was calculated by dividing the total number of crabs collected in $1 \mathrm{wk}$ by the total number of pots fished within that week. Sex-specific patterns in crab $\mathrm{CW}$ were also evaluated in the context of water temperature, salinity, and daylength. Tukey's test was used when post hoc multiple comparisons were needed. All significance levels were set at alpha $=0.05$ a priori .

The environmental variables bottom water temperature (measured in degrees Celsius), salinity, and daylength (measured in hours) were categorized to have at least 10 CPUE values per category for statistical robustness. Water temperature was categorized as less than $20^{\circ} \mathrm{C}, 20-25.9^{\circ} \mathrm{C}$, or greater than or equal to $26^{\circ} \mathrm{C}$. Harding and Mann (2010) describe $18-20^{\circ} \mathrm{C}$ as a spring threshold for increasing $\mathrm{CPUE}$, and $26^{\circ} \mathrm{C}$ as a fall threshold for declining CPUE on Palace Bar reef in the Piankatank River, VA, during 1996 and 1997. Salinity was categorized as less than 15 or greater than or equal to 15 . An average salinity of 15 was observed at Shell Bar reef from May through October from 2005 through 2009. Hourly salinities from June 2005 through November 2009 are available at www.vims.edu/mollusc/NORM/ envdata/03SBR.html. Daylength was categorized as less than $12 \mathrm{~h}, 12-13.9 \mathrm{~h}$, or greater than or equal to $14 \mathrm{~h}$ of light per day. Seasonal changes in daylength affected the observed CPUE and the proportion of male crabs during 1996 and 1997 at Palace Bar reef in the Piankatank River (Harding \& Mann 2010).

\section{Total Blue Crab Weekly CPUE}

The logarithm transformation was applied to the total weekly CPUE data to achieve homogeneity of variance and normality. The transformed data were evaluated with ANCOVA with year as a covariate, and water temperature, salinity, and daylength as fixed factors. The data set was too unbalanced to calculate interaction terms between variables.

\section{Proportion of Males in the Weekly CPUE}

The proportion that males contributed to the weekly CPUE was evaluated with ANCOVA with year as a covariate, and water temperature, salinity, and daylength as fixed factors. The proportion data satisfied the assumptions of normality and homogeneity of variance without transformation. This data set was also too unbalanced to calculate interaction terms.

\section{Crab Carapace Width in Relation to Sex, Water Temperature, Salinity, and Daylength}

The CW data set did not satisfy either the assumption of normality or homogeneity of variance regardless of the transformation (logarithm, natural logarithm, square root, arcsine), so parametric statistics were not used. Crab $\mathrm{CW}$ measurements were compared between sexes across years and between sexes across environmental factors by examining the sex-specific averages and corresponding $95 \%$ confidence intervals.

\section{RESULTS}

\section{Environmental Data}

Average weekly water temperatures during WOY 19 through 44 (approximately May through October) ranged from $14.0-31.0^{\circ} \mathrm{C}$ and from $17.5-29.5^{\circ} \mathrm{C}$ in 2006 and 2007, respectively (Table 1, Fig. 1A). The average bottom water temperatures from May through October 2006 and 2007 were $23.9^{\circ} \mathrm{C}$ $(\mathrm{SE}=0.33)$ and $24.7^{\circ} \mathrm{C}(\mathrm{SE}=0.25)$, respectively. As expected in a northern hemisphere temperate estuary, water temperatures during both years increased until WOY 31-32 (late July/early August) and then gradually declined from August through the end of the study in October (Fig. 1).

Average weekly salinities ranged from 13.6-16.4 and from 10.4-18.9 in 2006 and 2007, respectively (Table 1, Fig. 1B). The seasonal salinity trends observed in 2007 are typical because May is usually the end of the spring rainy season and has 
Blue Crabs on Constructed Oyster Reef

TABLE 1.

Summary of blue crab collections on Shell Bar oyster reef, Great Wicomico River, VA, during 2006 and 2007.

\begin{tabular}{|c|c|c|c|c|c|c|c|}
\hline Year & Week & $\begin{array}{l}\text { Average Weekly Bottom } \\
\text { Water Temperature }\left({ }^{\circ} \mathrm{C}\right)\end{array}$ & $\begin{array}{l}\text { Average Weekly } \\
\text { Bottom Salinity }\end{array}$ & $\begin{array}{l}\text { Average Weekly } \\
\text { Daylength (h) }\end{array}$ & $\begin{array}{c}\text { CPUE } \\
\text { (crabs/pot/wk) }\end{array}$ & $\begin{array}{l}\text { No. of } \\
\text { Females }\end{array}$ & $\begin{array}{l}\text { No. of } \\
\text { Males }\end{array}$ \\
\hline \multirow[t]{26}{*}{2006} & 19 & 18.6 & 13.0 & 14.1 & 2.44 & 11 & 33 \\
\hline & 20 & 19.7 & 14.1 & 14.3 & 2.61 & 3 & 44 \\
\hline & 21 & 20.4 & 15.0 & 14.4 & 4.61 & 13 & 70 \\
\hline & 22 & 23.9 & 15.2 & 14.6 & 7.39 & 12 & 121 \\
\hline & 23 & 22.9 & 16.0 & 14.7 & 6.94 & 15 & 110 \\
\hline & 24 & 22.9 & 15.7 & 14.8 & 8.56 & 24 & 53 \\
\hline & 25 & 26.9 & 16.2 & 14.8 & 11.38 & 73 & 109 \\
\hline & 26 & 26.4 & 16.0 & 14.8 & 16.11 & 133 & 157 \\
\hline & 27 & 27.3 & 16.0 & 14.7 & 22.94 & 101 & 312 \\
\hline & 28 & 27.4 & 16.3 & 14.6 & 17.89 & 106 & 216 \\
\hline & 29 & 29.5 & 14.8 & 14.5 & 25.5 & 64 & 140 \\
\hline & 30 & 28.7 & 14.8 & 14.3 & 26.47 & 59 & 391 \\
\hline & 31 & 31.1 & 14.9 & 14.1 & 32.06 & 73 & 440 \\
\hline & 32 & 29.7 & 14.9 & 13.9 & 26.44 & 69 & 169 \\
\hline & 33 & 27.9 & 14.9 & 13.6 & 17.22 & 106 & 204 \\
\hline & 34 & 28.1 & 15.5 & 13.4 & 15.5 & 95 & 184 \\
\hline & 35 & 27.0 & 16.4 & 13.1 & 17.44 & 40 & 117 \\
\hline & 36 & 24.7 & 15.7 & 12.8 & 14.5 & 99 & 162 \\
\hline & 37 & 24.1 & 15.1 & 12.5 & 12.33 & 97 & 125 \\
\hline & 38 & 23.0 & 15.3 & 12.3 & 9.67 & 74 & 100 \\
\hline & 39 & 22.6 & 15.8 & 12.0 & 11.22 & 53 & 48 \\
\hline & 40 & 21.6 & 16.1 & 11.7 & 10.00 & 114 & 66 \\
\hline & 41 & 19.9 & 15.7 & 11.4 & 11.06 & 111 & 66 \\
\hline & 42 & 18.7 & 15.9 & 11.1 & 4.11 & 11 & 26 \\
\hline & 43 & 15.4 & 16.1 & 10.9 & 7.94 & 89 & 54 \\
\hline & 44 & 14.0 & 16.1 & 10.7 & 6.56 & 35 & 24 \\
\hline \multirow[t]{27}{*}{2007} & 18 & 17.6 & 10.6 & 13.8 & 0.67 & 0 & 12 \\
\hline & 19 & 18.1 & 10.4 & 14.0 & 2.00 & 0 & 36 \\
\hline & 20 & 19.8 & 11.0 & 14.2 & 2.06 & 2 & 35 \\
\hline & 21 & 20.3 & 12.2 & 14.4 & 3.44 & 3 & 28 \\
\hline & 22 & 23.4 & 12.9 & 14.6 & 5.67 & 11 & 91 \\
\hline & 23 & 24.0 & 13.5 & 14.7 & 5.67 & 0 & 51 \\
\hline & 24 & 25.2 & 13.5 & 14.8 & 9.17 & 48 & 117 \\
\hline & 25 & 25.8 & 13.5 & 14.8 & 12.61 & 64 & 163 \\
\hline & 26 & 26.6 & 13.7 & 14.8 & 12.89 & 92 & 140 \\
\hline & 27 & 26.2 & 14.1 & 14.7 & 10.56 & 44 & 146 \\
\hline & 28 & 27.8 & 14.9 & 14.6 & 8.00 & 10 & 62 \\
\hline & 29 & 27.7 & 15.3 & 14.5 & 10.61 & 27 & 164 \\
\hline & 30 & 27.0 & 15.7 & 14.3 & 13.29 & 32 & 154 \\
\hline & 31 & 28.6 & 15.7 & 14.1 & 8.61 & 63 & 92 \\
\hline & 32 & 29.6 & 16.3 & 13.9 & 10.56 & 82 & 108 \\
\hline & 33 & 28.6 & 16.3 & 13.7 & 12.06 & 78 & 139 \\
\hline & 34 & 27.2 & 16.4 & 13.4 & 11.17 & 77 & 124 \\
\hline & 35 & 28.2 & 16.5 & 13.1 & 11.22 & 51 & 50 \\
\hline & 36 & 27.4 & 16.9 & 12.9 & 11.39 & 105 & 100 \\
\hline & 37 & 27.0 & 17.7 & 12.6 & 8.11 & 66 & 80 \\
\hline & 38 & 23.3 & 18.2 & 12.3 & 7.28 & 75 & 56 \\
\hline & 39 & 24.3 & 18.1 & 12.0 & 9.22 & 67 & 16 \\
\hline & 40 & 23.8 & 18.6 & 11.7 & 12.5 & 77 & 23 \\
\hline & 41 & 24.2 & 18.6 & 11.5 & 6.00 & 73 & 35 \\
\hline & 42 & 21.4 & 18.9 & 11.2 & 3.44 & 19 & 12 \\
\hline & 43 & 21.5 & 18.8 & 10.9 & 3.94 & 49 & 22 \\
\hline & 44 & 18.8 & 18.2 & 10.7 & 3.56 & 24 & 8 \\
\hline
\end{tabular}

concurrently low salinities (Fig. 1B). The regional dry season is from June through November, with increasing salinities usually observed from early July through October (Fig. 1B). Regional precipitation levels from January through March were lower in
2006 (total precipitation, $11.0 \mathrm{~cm}$ ) than in 2007 (total precipitation, $25.1 \mathrm{~cm}$, Climatological Data for VA, 2006 and 2007), resulting in higher salinities in early spring 2006 than those observed in 2007 (Fig. 1B). In July and August 2006, 

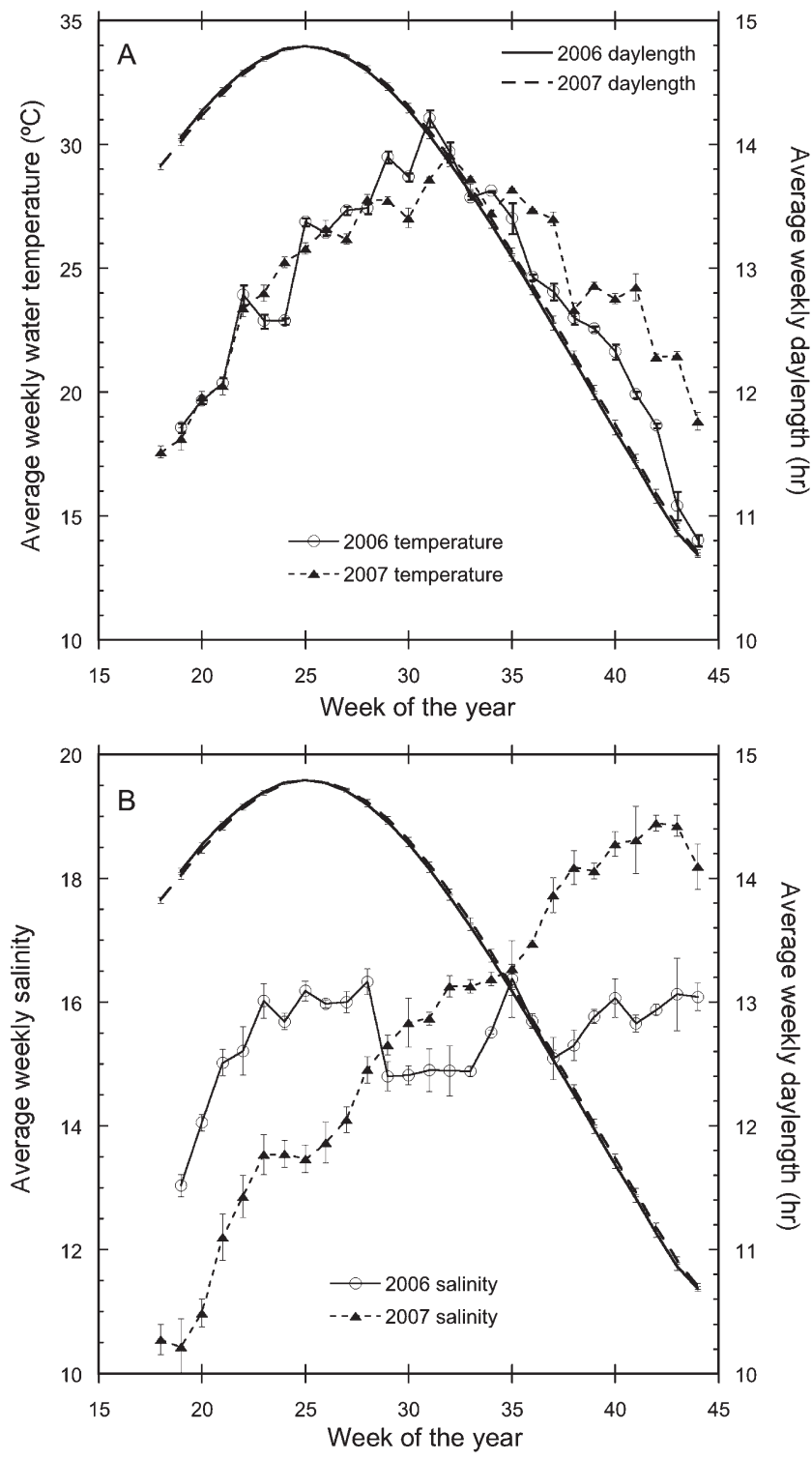

Figure 1. (A, B) Summary of water temperature $\left({ }^{\circ} \mathrm{C}\right)$, salinity, and daylength (h) conditions on Shell Bar reef in the Great Wicomico, VA, during 2006 (A) and 2007 (B). Average weekly water temperature and salinity (with SEM) were calculated from data collected every $15 \mathrm{~min}$ by a YSI 600 series sonde moored on Shell Bar reef. Daylength for the river was calculated from sunrise and sunset times.

including WOY 27 through 35, the Great Wicomico region received $16.5 \mathrm{~cm}$ rain compared with $15.0 \mathrm{~cm}$ rain during the same weeks in 2007 (Climatological Data for VA, 2006 \& 2007). Rainfall totals in September and October 2006 (47.4 cm) were higher than those recorded during the same period in 2007 (13.2 $\mathrm{cm})$, and salinities during WOY 36 through 44 were lower in 2006 than in 2007 (Fig. 1B). Average weekly daylength ranged from $10.8-14.8 \mathrm{~h}$ in both years (Fig. 1).

\section{Total Weekly Crab CPUE}

The total number of crabs collected in 2006 and 2007 was 5,221 and 3,303, respectively. The overall annual ratio of females to males was 0.47 in 2006 and 0.60 in 2007 (Table 1).
Weekly CPUE was significantly higher in 2006 than in 2007 (ANCOVA; Table 2, Fig. 2). In general, CPUE increased with increasing water temperatures up to the seasonal temperature maximum, with maximum weekly CPUEs observed in late July at WOY 31 in 2006 (32.06; Table 1, Fig. 2) and WOY 30 in 2007 (13.29; Table 1, Fig. 2). When water temperatures were equal to or more than $26^{\circ} \mathrm{C}$, crab CPUE was significantly higher than at lower temperatures (ANCOVA, Table 2). CPUEs were highest from approximately WOY 25 (mid-June)-37 (mid-September) in both years (Table 1).

\section{Proportion of Males in the Weekly CPUE}

Males made up at least $50 \%$ of the crabs caught before early September (WOY 36-37) in both 2006 and 2007 (Table 1, Fig. 3). Neither year nor water temperature significantly affected the observed proportion of male crabs caught (ANCOVA, Table 2). After WOY 37, the proportion of males declined significantly with decreasing daylength and increasing salinities through the end of October. Males made up the smallest proportion of the catch at daylengths less than $12 \mathrm{~h}$ (late September through October) and the greatest proportion at daylengths greater than or equal to $14 \mathrm{~h}$ (May through early August; ANCOVA, Table 2 ). The proportion of males caught was significantly less at salinities greater than or equal to 15 than at lower salinities (ANCOVA, Table 2).

Crab Carapace Width in Relation to Sex, Water Temperature, Salinity, and Daylength

Female crabs were approximately $20 \mathrm{~mm}$ larger in $\mathrm{CW}$ than males in both years (Figs. 4, 5, and 6A, Table 1). The median female CW was $142 \mathrm{~mm}$ in $2006(n=1,680)$ and $144 \mathrm{~mm}$ in 2007 $(n=1,239)$. The median male $\mathrm{CW}$ was $125 \mathrm{~mm}$ in both 2006 $(n=3,541)$ and in $2007(n=2,064)$. Hines et al. (1987) also describe an approximately $20-\mathrm{mm}$ difference in male (mode, 135 $\mathrm{mm}$ ) and female (mode, $155 \mathrm{~mm}$ ) crab population demographics in the Rhode River, MD, from 1983 through 1985.

Females and males that were larger than the median CW dominated the catch during WOY 24-26 (June) in 2006 and 2007 (Figs. 4 and 5). These relatively larger crabs may have overwintered in the Great Wicomico River and been captured on the reef as they were migrating down the estuary. The average $\mathrm{CW}$ for both sexes was larger at water temperatures less than $26^{\circ} \mathrm{C}$ than at warmer temperatures (Fig. 6B). Although average male $\mathrm{CW}$ was similar across salinities, the largest females were observed at salinities greater than or equal to 15 (Fig. 6C). Male crabs were smaller when daylengths were between 12 and 13. 9 h (early May, early August through September) than at either less than $12 \mathrm{~h}$ (October) or greater than $14 \mathrm{~h}$ (mid-May through July, Fig. 6D).

\section{DISCUSSION}

Blue crab CPUE at Shell Bar reef in both years examined was highest from mid June through mid September at water temperatures at or more than $26^{\circ} \mathrm{C}$. Males made up more than $50 \%$ of the catch at Shell Bar reef from May through August. The observed sex ratios shifted from male dominated to female dominated as salinities increased, whereas water temperatures and daylength decreased seasonally. Similar seasonal changes in crab population sex ratios and demographics have been previously observed in other Chesapeake Bay tributaries 
TABLE 2.

Summary of statistical tests used to describe blue crab patterns of habitat use at Shell Bar reef, Great Wicomico River, VA, during 2006 and 2007.

\begin{tabular}{cccccccc}
\hline \hline Test & Response & Factor & Covariate & df & F Value & $\boldsymbol{P}$ Value & Post Hoc Multiple Comparison \\
\hline ANCOVA & Weekly CPUE & & Year & 1 & 27.56 & $<0.01^{*}$ & $2006>2007$ \\
& & WT & & 2 & 46.44 & $<0.01^{*}$ & $\left(\geq 26^{\circ} \mathrm{C}\right)>\left(20-25.9^{\circ} \mathrm{C}\right)>\left(<20^{\circ} \mathrm{C}\right)$ \\
& & Salt & & 1 & 0.62 & 0.43 & \\
ANCOVA & Proportion male & DL & & 2 & 2.92 & 0.06 & \\
& & & Year & 1 & 3.99 & 0.72 & \\
& & WT & & 2 & 2.62 & 0.08 & $(<15)>(\geq 15)$ \\
& & Salt & & 1 & 5.21 & 0.03 & $(\geq 14 \mathrm{~h})>(12-13.9 \mathrm{~h})>(<12 \mathrm{~h})$ \\
\hline
\end{tabular}

Tukey's test was used for post hoc multiple comparisons. Asterisks indicate statistical significance at alpha $=0.05$.

DL, daylength in hours; WT, water temperature in degrees Celsius.

(Rhode River, MD (Hines et al. 1987); Piankatank River, VA (Harding \& Mann 2010)). Male crabs typically migrate to upper estuary habitats in the late summer (Churchill 1919, Van Engel 1958, Hines et al. 1987). Postcopulatory females occupy mating habitats in Chesapeake tributaries until the fall (September to November (Anguilar et al. 2005)). Female crabs observed in the Great Wicomico River in September and October were likely migrating from tributary mating habitats toward down-Bay spawning habitats.

The annual average CPUE on Shell Bar reef in 2007, 7.98 crabs per pot ( $\mathrm{SE}=0.78)$, is of the same order of magnitude as those reported for a constructed oyster reef (6-8 crabs per pot, 1996 to 1997 (Harding \& Mann 2010)), an oyster bar (9.2 crabs per pot, 1997 (Harding \& Mann 2010)), and a sand bar (6.1 crabs per pot, 1997 (Harding \& Mann 2010)) in the Piankatank River, VA, and near Calvert Cliffs, MD (3-8 crabs per pot, 1990

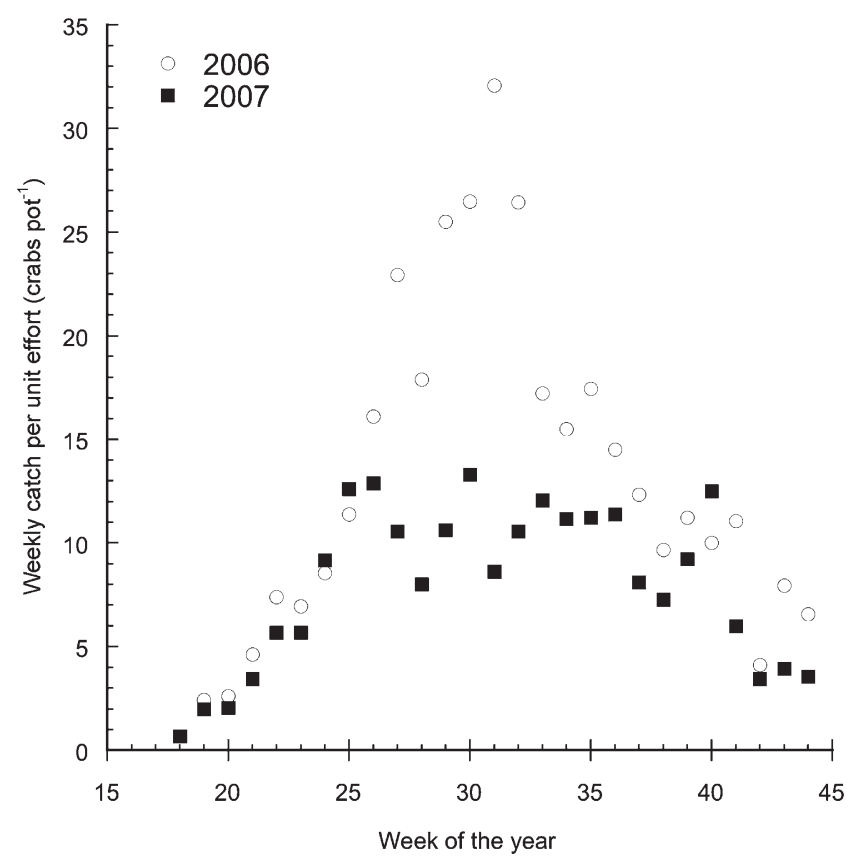

Figure 2. Weekly blue crab catch per unit effort at Shell Bar reef in 2006 and 2007. to 2000 (Abbe 2002)). The maximum CPUE at Shell Bar reef in 2007 (13.3 crabs per pot) was similar to the maximum CPUE observed at Palace Bar reef in the Piankatank River in 1996 and 1997 (15.8 crabs per pot (Harding \& Mann 2010)) as well as the maximum CPUEs of 13.7 and 13.5 crabs per pot observed in 1997 at a Piankatank River oyster bar and sand bar, respectively (Harding \& Mann 2010). Both annual average CPUE (13.42 crabs per pot, $\mathrm{SE}=1.57)$ and maximum CPUE $(32.06$ crabs per pot) at Shell Bar reef were almost twice as high in 2006 when compared with 2007 (Fig. 2).

It is unlikely that the observed interannual difference in CPUE resulted from differences in environmental conditions. Weekly average water temperatures at Shell Bar reef were within $1-2^{\circ} \mathrm{C}$ of each other in 2006 and 2007, and followed the same general trend in both years (Fig. 1). Salinities observed at Shell Bar reef from midsummer through fall 2006 were

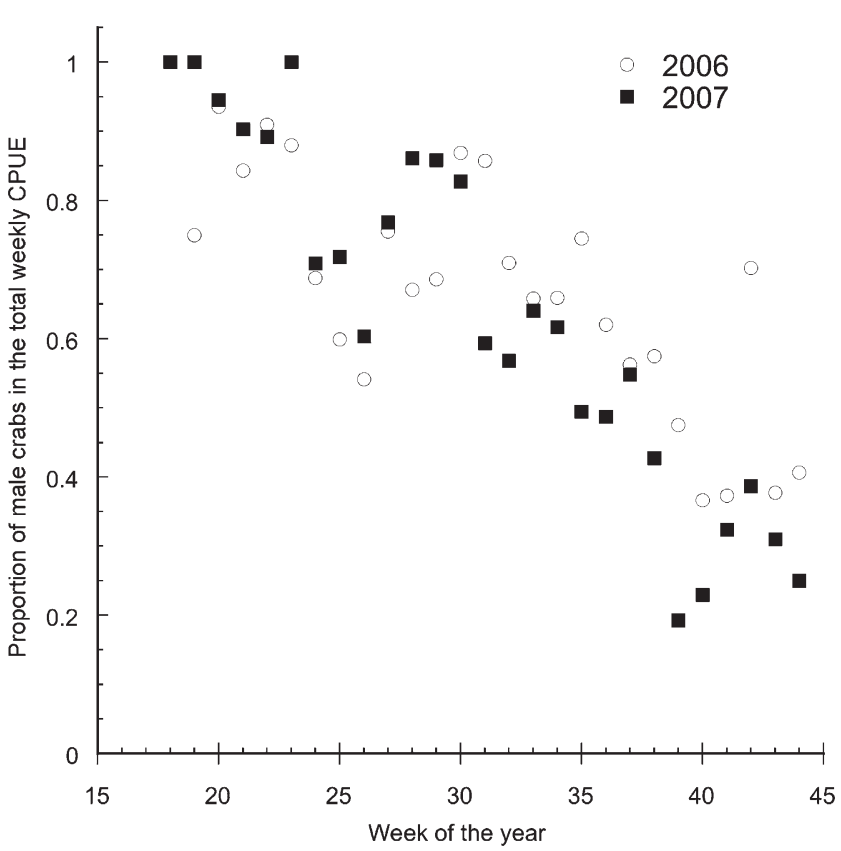

Figure 3. Proportion of the total number of blue crab catch as males over time at Shell Bar reef during 2006 and 2007. 

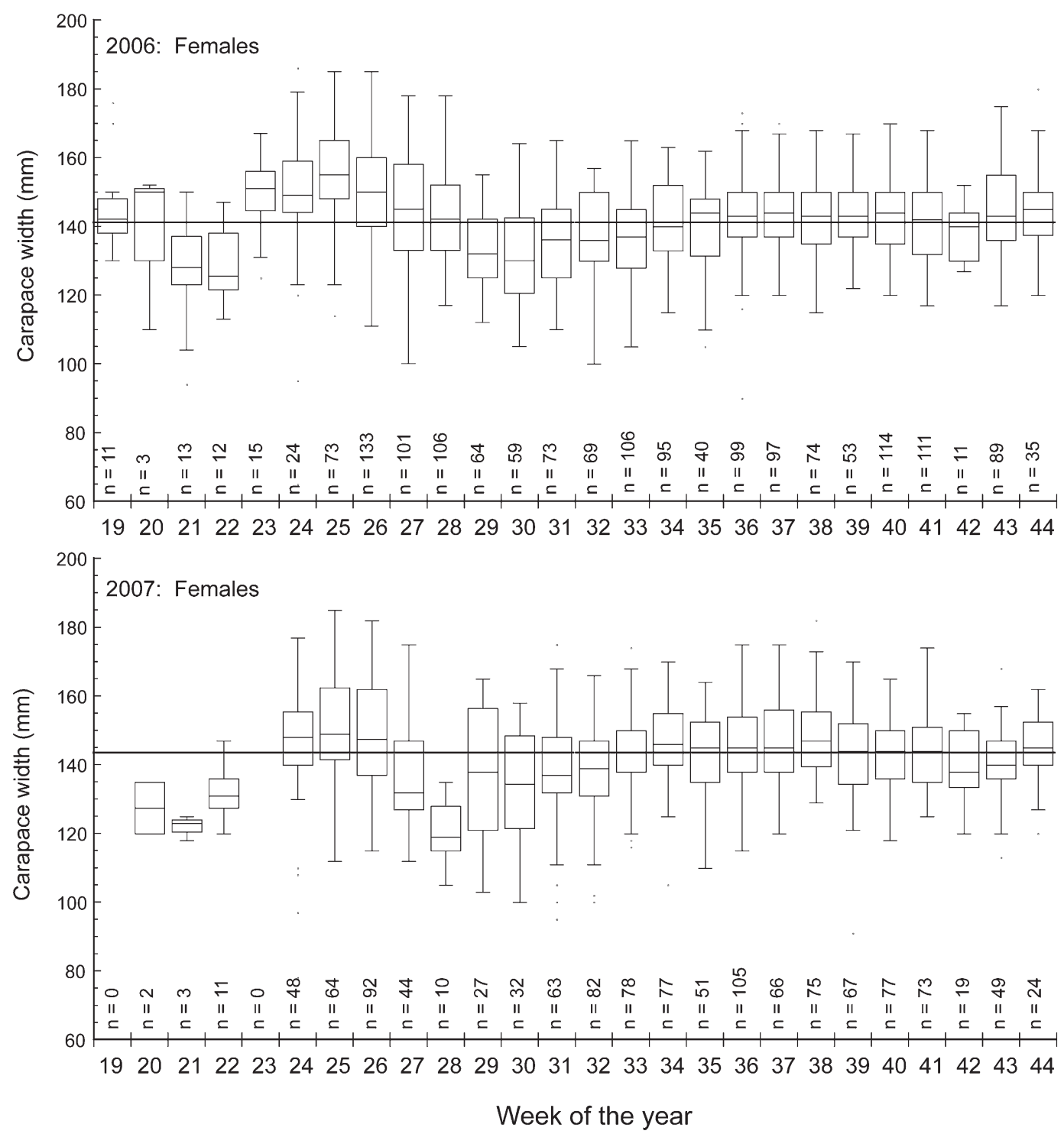

Figure 4. (A, B) Carapace width for female blue crabs collected from Shell Bar reef in 2006 (A) and 2007 (B). The solid horizontal line is the median CW of all female crabs captured within that year (2006: $142 \mathrm{~mm}$, total annual $n=1,680 ; 2007: 144 \mathrm{~mm}, n=1,239)$. The number of crabs $(n)$ for each collection are given above the $\mathrm{x}$-axis. NS, not sampled.

generally lower than those observed in 2007 (Fig. 1), but were still within the 14-16 range. Modest differences in annual estimates of blue crab harvest in Virginia for $2006\left(20.8 \times 10^{6}\right.$ lbs (Chesapeake Bay Blue Crab Advisory Report 2007)) and $2007\left(17.4 \times 10^{6} \mathrm{lbs}\right.$ (Chesapeake Bay Blue Crab Advisory Report 2008)) are not of the same scale as the observed differences in 2006 and 2007 CPUE at Shell Bar reef in the Great Wicomico River.

The portion of the Great Wicomico estuary below Horn Harbor $\left(37.85^{\circ} \mathrm{N}, 76.344^{\circ} \mathrm{W}\right)$ has been the site of intensive oyster rehabilitation and monitoring efforts since the construction of Shell Bar reef in 1996 (Southworth \& Mann 1998). As part of this multiagency program, 9.11 million cultchless cultured oysters were planted on Shell Bar reef from May through September 2006 (Mann et al. 2008, Leggett 2007 (unpublished annual oyster transplanting report; Chesapeake Bay Foundation, Gloucester Point, VA)). The addition of cultured cultchless oysters to constructed reef structures has been an oyster population enhancement strategy in Virginia since the mid-1990s and is intended to increase broodstock oyster densities quickly on reefs. The majority ( 8.78 million) of the oysters placed on Shell Bar reef in 2006 were $40-50 \mathrm{~mm}$ in shell height, within the size range of vulnerability for predation by the observed demographics of crabs (see Eggleston 1990a, Eggleston 1990b). Although Shell Bar reef also received 22,000 cultchless oysters in May 2007 (Leggett 2007 (unpublished annual oyster transplanting report; Chesapeake Bay Foundation, Gloucester Point, VA)), the 2006 additions of oysters were much larger in magnitude and occurred over a longer time period than the 2007 plantings.

Oyster planting data and crab CPUE data were collected on different timescales as components of independent projects. The crab CPUE data were standardized by the number of days for each soak to provide a daily estimate for CPUE to enable a comparison of the oyster and crab data sets. Daily oyster 


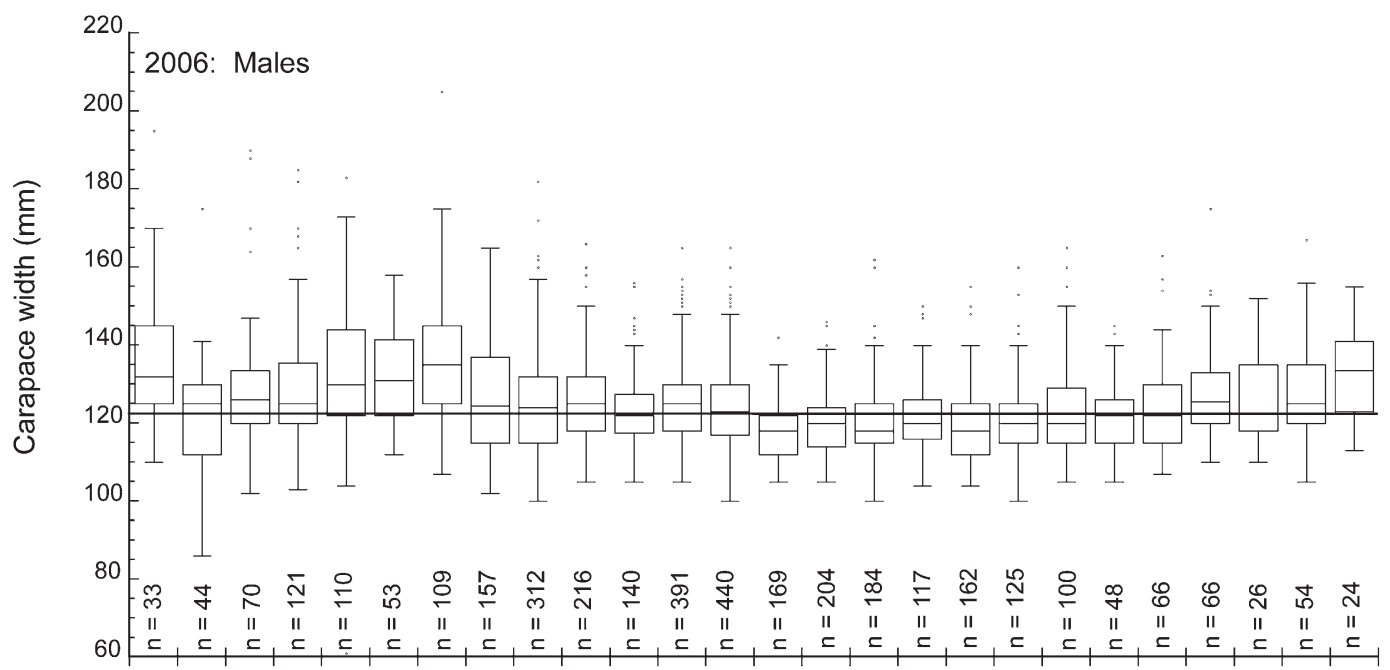

$\begin{array}{llllllllllllllllllllllllll}19 & 20 & 21 & 22 & 23 & 24 & 25 & 26 & 27 & 28 & 29 & 30 & 31 & 32 & 33 & 34 & 35 & 36 & 37 & 38 & 39 & 40 & 41 & 42 & 43 & 44\end{array}$

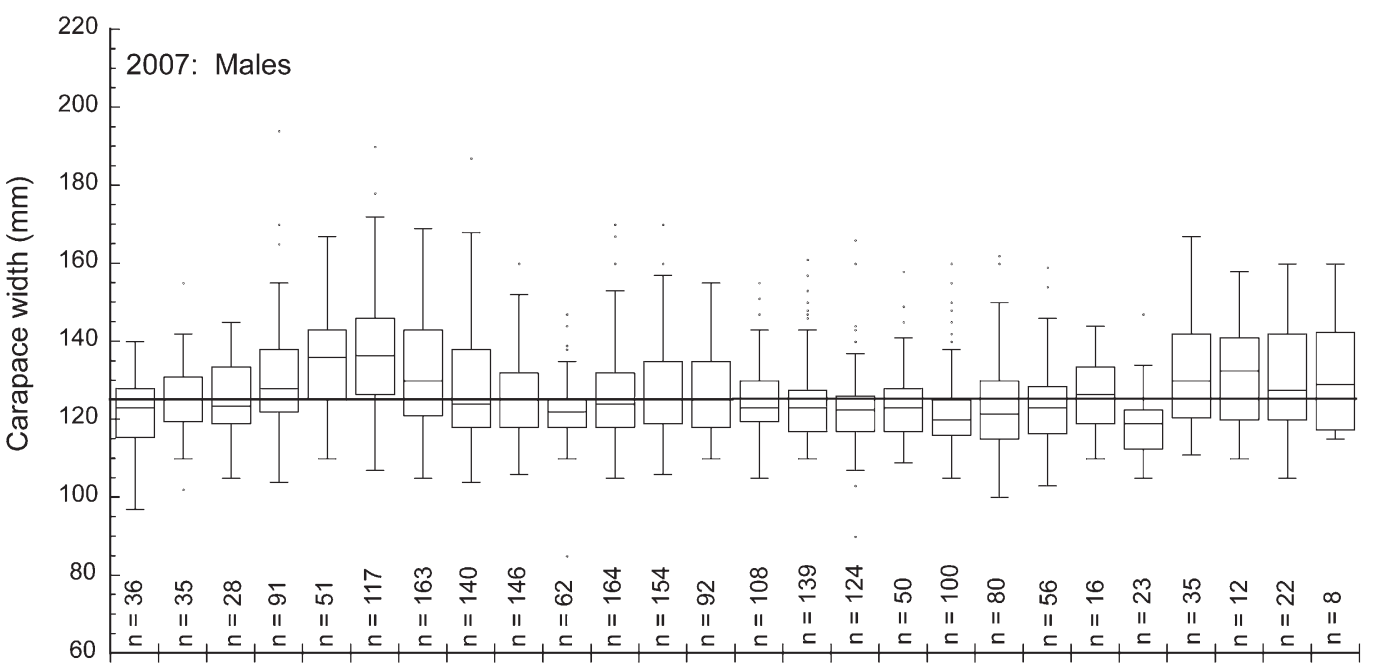

$19202122 \quad 2324252627282930 \quad 3132 \quad 33 \quad 34 \quad 35 \quad 36 \quad 3738 \quad 3940 \quad 41424344$

\section{Week of the year}

Figure 5. Carapace width for male blue crabs collected from Shell Bar reef in 2006 (A) and 2007 (B). The solid horizontal line is the median CW of all male crabs captured within that year (2006: $125 \mathrm{~mm}$, total annual $n=3,541 ; 2007: 125 \mathrm{~mm}, n=2,064)$. The number of crabs $(n)$ for each collection are given above the $\mathrm{x}$-axis. NS, not sampled.

planting data from 2006 and the difference in standardized daily crab CPUE from mid June through mid-September 2006 and 2007 were examined (WOY 26-39, when the highest crab CPUEs were observed; Fig. 7). The daily crab CPUE in 2006 increased after oysters were planted and remained higher than 2007 daily values for up to $2 \mathrm{wk}$ after a planting event for 4 of the 6 observed increases in CPUE between 2006 and 2007 (Fig. 7). These data suggest that placement of cultured oysters may have enhanced the observed crab abundance on Shell Bar reef in summer 2006 by potentially increasing the forage base. A diver survey of Shell Bar reef in September 2006 estimated a standing stock of 2.15 million cultured cultchless oysters (Mann et al. 2008). This estimate is approximately $24 \%$ of the 9.11 million cultchless oysters (all sizes) planted from May through September 2006. The difference between the sum of oysters planted in summer 2006 and those observed on the reef in September 2006 is the result, at least in part, of crab predation on the planted oysters. Mortality directly from planting and seasonal onset of disease may have also killed some of the cultchless oysters.

When cultured oysters are placed on constructed reefs in Virginia, they are typically spread onto the reef surface en masse, and individual oysters may be damaged during the process. Damaged oysters, particularly in large numbers, might provide chemical cues that would attract predators including blue crabs. Seitz et al. (2003) describe food availability as the main factor controlling blue crab densities at spatial scales less than $10 \mathrm{~km}$. Although Peterson et al. (2003) suggest that oyster reef restoration efforts enhance crab production locally by increasing structural habitat and food resources, they assumed that oyster populations and biogenic habitats on rehabilitated reefs were self-sustaining. Thus, they did not explicitly consider the effects of cultured oyster planting on reef community rehabilitation. Our data suggest a short-term enhancement of crabs and concurrent reduction in planted oyster populations 

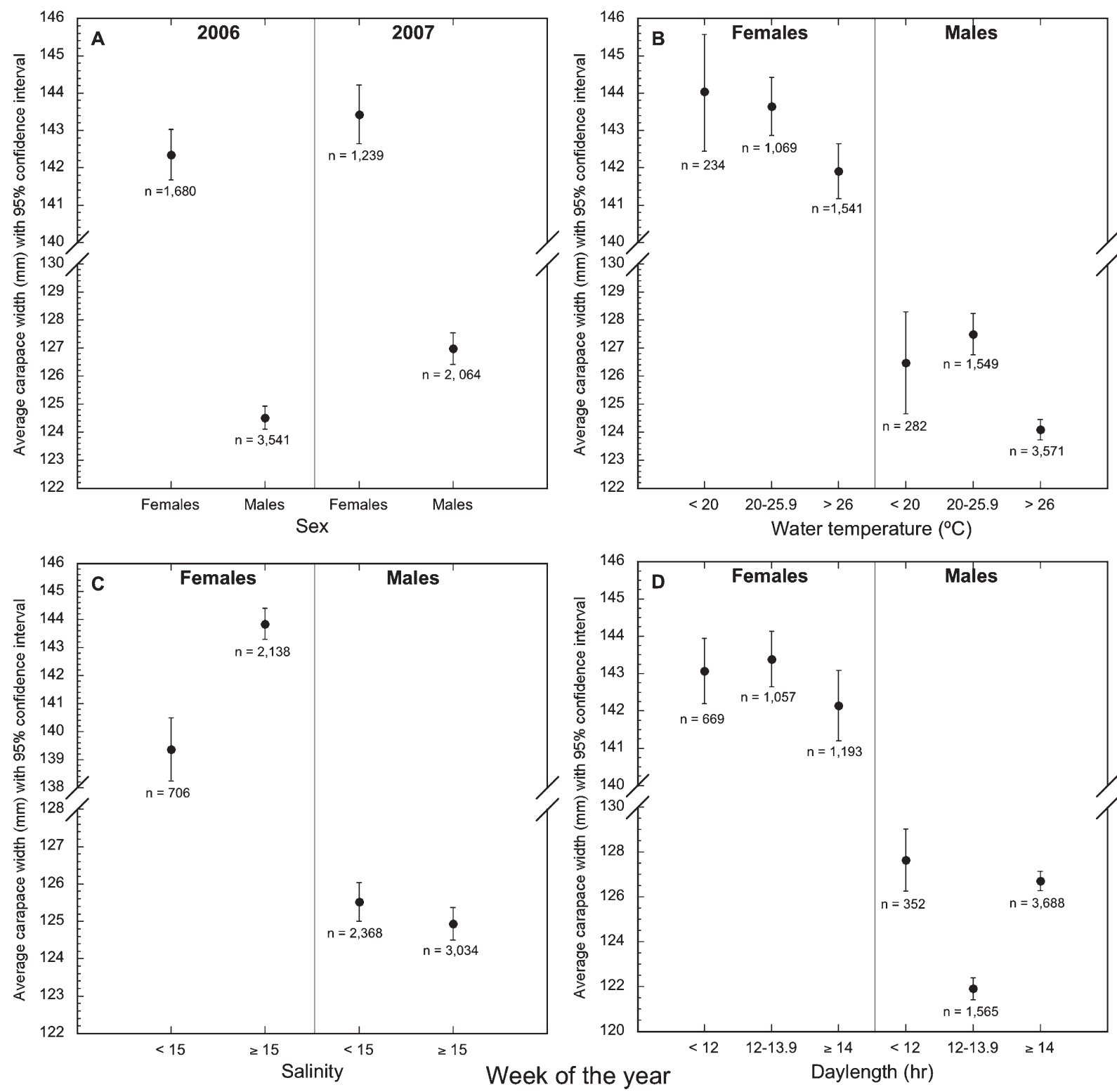

Figure 6. (A-D) Comparisons of average crab carapace width with $95 \%$ confidence intervals by sex across years (A), across sexes with regard to water temperature (B), salinity (C), and daylength (D). The number of individual crab carapace width measurements (n) contributing to each data point are provided below the data point.

on constructed reefs when cultchless oysters are planted. Crab populations in the vicinity will likely return to preplanting levels after the planted oysters are consumed. Future deployments of cultchless oysters as an oyster population enhancement tool on constructed reefs should consider cultured oyster size, planting method, and the timing of deployment relative to seasonal patterns of predator abundance in the habitat. Recent oyster rehabilitation efforts in both Maryland and Virginia have incorporated remote setting or planting of spat-on-shell, shell to which cultured oysters have been allowed to metamorphose in high density, to reduce predation mortality.

The status of both oyster and crab resources within the modern Chesapeake Bay is of interest to resource managers, the seafood industry, and the general public. Restoration and conservation efforts aimed at one species will affect the other.
Recent assessment of oyster reefs in the context of essential fish habitat (e.g., Coen et al. 1999, Minello 1999, Peterson et al. 2003) has demonstrated that oyster reefs provide valuable trophic resources and habitat for crabs at local spatial scales. Data sets such as this one, which provide basic descriptive information for crab populations in specific estuaries at small spatial scales over multiple years, are important for evaluating habitat rehabilitation efforts and community dynamics.

\section{ACKNOWLEDGMENTS}

Raymond Kellum, Anthony Kellum, and Steve Kellum checked the crab pots weekly and delivered the catch to the Virginia Institute of Marine Science (VIMS). Meghan Harris, 


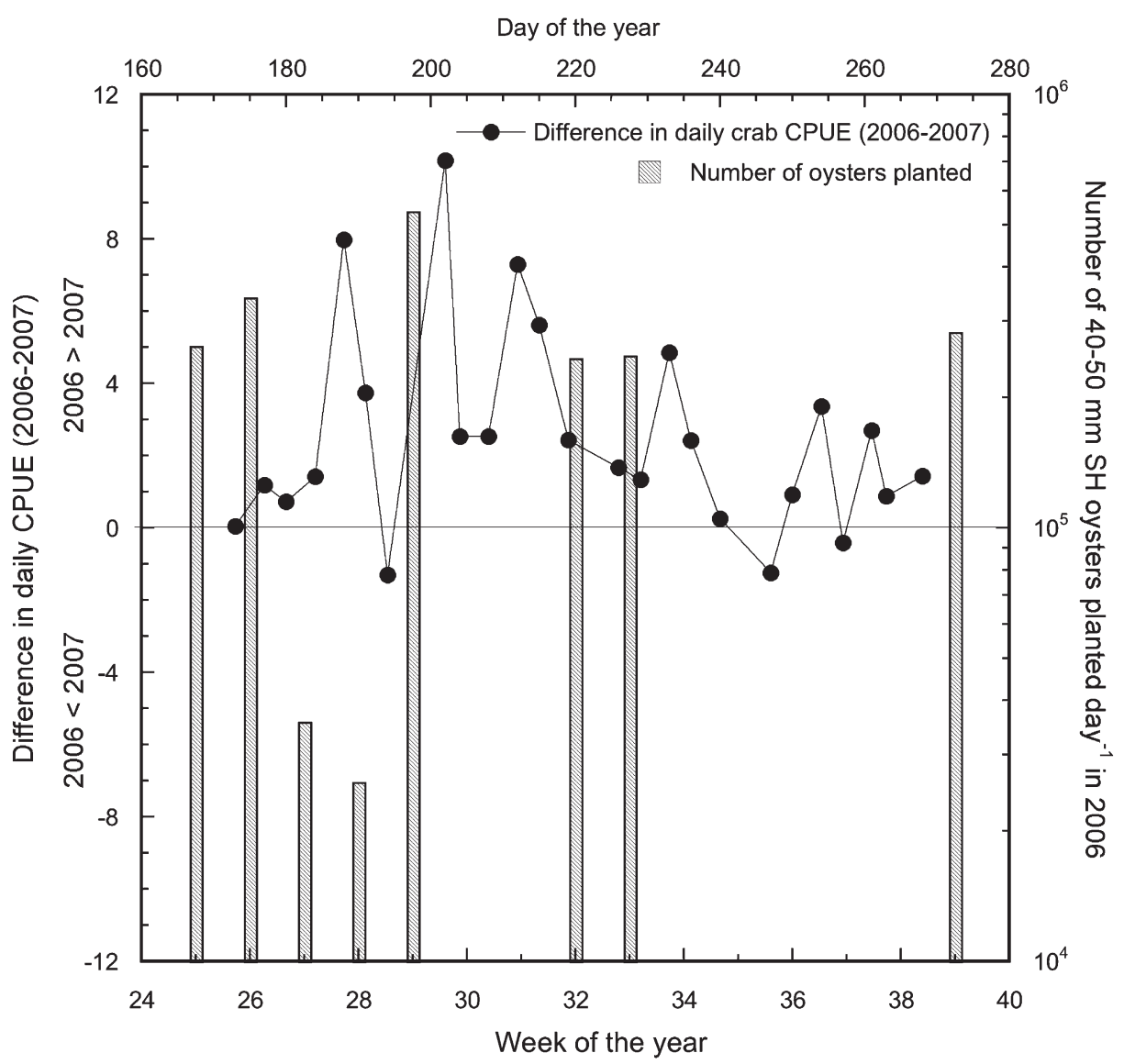

Figure 7. Differences in the standardized daily blue crab CPUE at Shell Bar reef between 2006 and 2007 in relation to the number of 40-50-mm shell height $(\mathrm{SH}, \mathrm{mm})$ cultured oysters planted as part of oyster enhancement efforts.

Stefanie Gera, Matthew Robinson, Karen Capossela, and Erin Reilly helped measure crabs. Funding for this project was provided by the VIMS Department of Fisheries Science, the US Army Corps of Engineers (W91236-05-C-0059 and
W91236-07-P-0053), and the NOAA Chesapeake Bay Office (NA06NMF4570312 and NA07NMF4570335). This is contribution no. 3114 from the Virginia Institute of Marine Science, College of William and Mary, Gloucester Point, Virginia.

\section{LITERATURE CITED}

Abbe, G. 2002. Decline in size of male blue crabs (Callinectes sapidus) from 1968 to 2000 near Calvert Cliffs, Maryland. Estuaries 25:105114.

Andrews, J. D. 1979. Pelecypoda: Ostreidae. In: A. C. Giese \& J. S. Pearse, editors. Reproduction of marine invertebrates. New York: Academic Press. pp. 293-341.

Anguilar, R., A. Hines, T. Wolcott, D. Wolcott, M. Kramer \& R. Lipcius. 2005. The timing and route of movement and migration of post-copulatory female blue crabs, Callinectes sapidus Rathbun, from the upper Chesapeake Bay. J. Exp. Mar. Biol. Ecol. 319:117-128.

Chesapeake Bay Blue Crab Advisory Report. 2007. Annapolis, MD: Chesapeake Bay Stock Assessment Committee, NOAA Chesapeake Bay Program.

Chesapeake Bay Blue Crab Advisory Report. 2008. Annapolis, MD: Chesapeake Bay Stock Assessment Committee, NOAA Chesapeake Bay Program.

Churchill, E. 1919. Life history of the blue crab. Bull. U.S. Bureau Fish. XXXVI:91-128.

Climatological data for Virginia: annual summary. National Oceanic and Atmospheric Administration, Department of Commerce. Vols. $2006116(13)$ and 2007 117(13).
Coen, L. \& M. Luckenbach. 2000. Developing success criteria and goals for evaluating shellfish habitat restoration: ecological function or resource exploitation? Ecol. Eng. 15:323-343.

Coen, L., M. Luckenbach \& D. Breitburg. 1999. The role of oyster reefs as essential fish habitat: a review of current knowledge and some new perspectives. In: L. R. Benaka, editor. Fish habitat: essential fish habitat and rehabilitation. Am. Fish. Soc. Symp. 22, Bethesda: American Fisheries Society. pp. 438-454.

Eggleston, D. 1990a. Foraging behavior of the blue crab, Callinectes sapidus, on juvenile oysters, Crassostrea virginica, effects of prey density and size. Bull. Mar. Sci. 46:62-82.

Eggleston, D. 1990b. Functional responses of blue crabs Callinectes sapidus Rathbun feeding on juvenile oysters Crassostrea virginica Gmelin: effects of predator sex and size, and prey size. J. Exp. Mar. Biol. Ecol. 143:73-90.

Glancy, T., T. Frazer, C. Cichra \& W. Lindberg. 2003. Comparative patterns of occupancy by decapod crustaceans in seagrass, oyster, and marsh-edge habitats in a northeast Gulf of Mexico estuary. Estuaries 26:1291-1301.

Harding, J. M. \& R. Mann. 2010. Observations of distribution, size, and sex ratio of mature blue crabs Callinectes sapidus Rathbun 1896, 
from a Chesapeake Bay tributary in relation to oyster habitat and environmental factors. Bull. Mar. Sci. 86:75-91.

Hargis, W. J., Jr. \& D. S. Haven. 1999. Chesapeake oyster reefs, their importance, destruction and guidelines for restoring them. In: M. W. Luckenbach, R. Mann, \& J. A. Wesson, editors. Oyster reef habitat restoration: a synopsis and synthesis of approaches. Gloucester Point, VA: Virginia Institute of Marine Science Press. pp. 328-359.

Haven, D. S., J. Whitcomb \& P. Kendall. 1981. The present and potential productivity of the Baylor Grounds in Virginia. Special Report in Applied Marine Science and Ocean Engineering No. 243. Gloucester Point, VA: Virginia Institute of Marine Science. 154 pp.

Hines, A. H., A. M. Haddon \& L. A. Wiechert. 1990. Guild structure and foraging impact of blue crabs and epibenthic fish in a subestuary of Chesapeake Bay. Mar. Ecol. Prog. Ser. 67:105-126.

Hines, A., R. Lipcius \& A. Haddon. 1987. Population dynamics and habitat partitioning by size, sex, and molt stage of blue crabs Callinectes sapidus in a subestuary of central Chesapeake Bay. Mar. Ecol. Prog. Ser. 36:55-64.

Hines, A., T. G. Wolcott, E. Gonzalez-Gurriaran, J. L. GonzalezGurriaran \& J. Friere. 1995. Movement patterns and migrations in crabs: telemetry studies of juvenile and adult behavior in Callinectes sapidus and Maja squinado. J. Mar. Biol. Assoc. UK. 75:27-42.

Hyer, P. \& L. Jacobsen. 1976. Hydrography and hydrodynamics of Virginia estuaries: IX. Mathematical water quality study of Great Wicomico River and Cockrell Creek. Special Report in Applied Marine Science and Ocean Engineering No. 120., Gloucester Point, VA. VIMS. 122 p.

Lipcius, R. \& W. T. Stockhausen. 2002. Concurrent decline of the spawning stock, recruitment, larval abundance, and size of the blue crab Callinectes sapidus in Chesapeake Bay. Mar. Ecol. Prog. Ser. 226:45-61.

Lipcius, R., W. Stockhausen, R. Seitz \& P. J. Geer. 2003. Spatial dynamics and value of a marine protected area and corridor for the blue crab spawning stock in Chesapeake Bay. Bull. Mar. Sci. 72: 453-469.

Lipcius, R. \& W. Van Engel. 1990. Blue crab population dynamics in Chesapeake Bay: variation in abundance (York River, 1972-1988) and stock recruit functions. Bull. Mar. Sci. 46:180-194.

Mann, R., S. K. Allen, Jr., E. M. Burreson, M. W. Luckenbach, K. S. Reece, J. M. Harding, M. J. Southworth, R. Carnegie \& J. Cordes. 2008. Native oyster restoration in the Virginia portion of the Chesapeake Bay. Progress report for 2007 to NOAA Chesapeake Bay Office. Gloucester Point, VA: Virginia Institute of Marine Science. 145 pp.
Millikin, M. \& A. Williams. 1984. Synopsis of biological data on the blue crab Callinectes sapidus, Rathbun. NOAA Technical report NMFS 1. FAO fisheries synopsis no. 138. Washington, D.C.: U.S. Department of Commerce. 39 pp.

Minello, T. 1999. Nekton densities in shallow estuarine habitats of Texas and Louisiana and the identification of essential fish habitat. In: L. Benaka, editor. Fish habitat: essential fish habitat and rehabilitation. Bethesda, MD: Am. Fish. Soc. Symp. 22. pp. 43-75.

Orth, R. 1977. The importance of sediment stability in seagrass communities. In: B. C. Coull, editor. Ecology of marine benthos. Columbia: University of South Carolina Press. pp. 281-300.

Orth, R. \& J. von Montfrans. 1987. Utilization of a seagrass meadow and a marsh tidal creek by blue crabs Callinectes sapidus. 1. Seasonal and annual variations in abundance with emphasis on post-settlement juveniles. Mar. Ecol. Prog. Ser. 41:283-294.

Peterson, C., J. Grabowski \& S. Powers. 2003. Estimated enhancement of fish production resulting from restoring oyster reef habitat: quantitative valuation. Mar. Ecol. Prog. Ser. 264:249-254.

Posey, M., T. Alpin, C. Powell \& E. Townsend. 1999. Oyster reefs as habitat for fish and decapods. In: M. W. Luckenbach, R. Mann, \& J. A. Wesson, editors. Oyster reef habitat restoration: a synopsis and synthesis of approaches. Gloucester Point, VA: Virginia Institute of Marine Science Press. pp. 229-237.

Rothschild, B. J., J. Ault, P. Goulletquer \& M. Heral. 1994. Decline of the Chesapeake Bay oyster population: a century of habitat destruction and overfishing. Mar. Ecol. Prog. Ser. 111:29-39.

Rugulo, L., K. Knotts, A. Lange \& V. Crecco. 1998. Stock assessment of Chesapeake Bay blue crab (Callinectes sapidus, Rathbun). J. Shellfish Res. 17:493-517.

Seitz, R., R. Lipcius \& M. Seebo. 2005. Food availability and growth of the blue crab in seagrass and unvegetated nurseries of Chesapeake Bay. J. Exp. Mar. Biol. Ecol. 319:57-68.

Seitz, R., R. Lipcius, W. Stockhausen, K. Delano, M. Seebo \& P. Gerdes. 2003. Potential bottom-up control of blue crab distribution at various spatial scales. Bull. Mar. Sci. 72:471-490.

Sogard, S. \& K. Able. 1994. Diel variation in immigration of fishes and decapod crustaceans to artificial seagrass habitat. Estuaries 17:622630.

Southworth, M. \& R. Mann. 1998. Oyster reef broodstock enhancement in the Great Wicomico River, Virginia. J. Shellfish Res. 17:1101-1114.

Van Engel, W. 1958. The blue crab and its fishery in Chesapeake Bay. Part 1: reproduction, early development, growth, and migration. Comm. Fish. Rev. 20:6-17.

Virnstein, R. 1977. The importance of predation by crabs and fishes on benthic infauna in Chesapeake Bay. Ecology 58:1199-1217. 